\title{
PEMBATALAN PERJANJIAN SEPIHAK MENURUT PASAL 1320 AYAT (1) KUH.PERDATA TENTANG KATA SEPAKAT SEBAGAI SYARAT SAHNYA PERJANJIAN
}

\author{
Suyanto ${ }^{1}$, Ayu Sulistiya Ningsih ${ }^{2}$ \\ 1. Dosen Program Studi Ilmu Hukum, Fakultas Hukum, Universitas Gresik \\ 2. Dosen Program Studi Ilmu Hukum, Fakultas Hukum, Universitas Gresik
}

\begin{abstract}
ABSTRAK
Penulisan penelitian ini bertujuan untuk mengetahui bagaimanakah pembatalan perjanjian secara sepihak dalam suatu perjanjian dan apa akibat-akibat jika kita membatalkan perjanjian secara sepihak dalam suatu perjanjian. Dengan menggunakan metode penelitian yuridis normatif dapat disimpulkan, bahwa dalam suatu perjanjian kesepakatan dalam perjanjian merupakan perwujudan dari kehendak dua atau lebih pihak dalam perjanjian mengenai apa yang mereka kehendaki untuk dilaksanakan, bagaimana cara melaksanakannya, kapan harus di laksanakan, dan siapa yang harus melaksanakan.Syarat batal suatu perjanjian diatur dalam Pasal 1266 KUH.Perdata yang menyebutkan syarat agar suatu perjanjian dapat dibatalkan oleh salah satu pihak adalah perjanjian harus timbal balik, terdapat wanprestasi, dan pembatalannya harus dimintakankepada hakim. jika pembatalan yang dilakukan tidak memenuhi syarat-syarat tersebut, maka dapat dikatakan perbuatan pembatalan tersebut melanggar undang-undang, yakni pasal 1266 KUH.Perdata tadi. Dari alasan pembatalan perjanjian, jika pembatalan tersebut mengandung kesewenang-wenangan, atau menggunakan posisi dominannya untuk memanfaatkan posisi lemah (keadaanmerugikan) pada pihak lawan, maka hal tersebut termasuk dalam perbuatan melawanhukum, karena melanggar kewajiban hukumnya untuk selalu beritikad baik dalam perjanjian
\end{abstract}

\section{Kata Kunci: Perjanjian, Syarat Sahnya Perjanjian, Pembatalan Perjanjian Sepihak}

\section{A. PENDAHULUAN}

\subsection{LATAR BELAKANG}

Dalam kehidupan sehari-hari, manusia tidak dapat terlepas dari hubungan dengan manusia lainnya untuk dapat memenuhi kebutuhan hidupnya. hubungan tersebut akan berlangsung baik apabila ada persesuaian kehendak diantara para pihak yang berhubungan.

Untuk mencapai kesesuaian kehendak dalam hubungan tersebut timbul suatu peristiwa dimana seseorang berjanji kepada orang lainnya untuk melakukan suatu hal. ${ }^{1}$ Hal itu dapat berupa kebebasan berbuat sesuatu., untuk menuntut sesuatu, untuk tidak berbuat sesuatu dan dapat berarti keharusan untuk menyerahkan sesuatu,

${ }^{1}$ Burgerlijk Wetboek, Kitab Undang-Undang Hukum Perdata, (terjemahan Subekti dan Tjitrosudibio), Cet-31, PT. Pradnya Paramitha, Jakarta, 2001, h. 338. untuk berbuat suatu hal, atau untuk tidak berbuat sesuatu.yang dimaksud perjanjian atau persetujuan yaitu hubungan yang dilakukan antara seseorang atau lebih dan badan hukum satu sama lain dimana mereka saling mengikatkan diri untuk memberikan sesuatu, untuk berbuat sesuatu, atau untuk tidak berbuat sesuatu. Jadi untuk melakukan perjanjian, haruslah memiliki tujuan yaitu prestasi yang akan dilaksanakan.

Istilah hukum perikatan merupakan terjemahan dari bahasa Belanda Verbintenissenrecht, hukum perikatan adalah keseluruhan peraturan hukum yang mengatur perikatan (Verbintenissen), apabila dikaji secara dalam definisi dari hukum perikatan adalah suatu kaidah-kaidah hukumyang mengatur hubungan hukum antara subjek hukum yang satu dengan subjek hukum yang lain dalam bidang harta 
kekayaan, dimana subjek hukum yang satu berhak atas suatu prestasi, sedangkan subjek hukum yang lain berkewajiban untuk memenuhi prestasi. ${ }^{2}$

Perikatan dapat lahir dari perjanjian Undang-Undang seperti yang disebutkan dalam Pasal 1233 Kitab Undang-Undang Hukum Perdata. $^{3}$ Perikatan yang timbul baik dari perjanjian, Undang-Undang dan putusan pengadilan akan melahirkan hak dan tanggung jawab yang dapat dituntut serta harus dipenuhi oleh masing-masing pihak. Namun dasar lahirnya perikatan tersebut mempunyai akibat yang berbeda bagi para pihak.

Dalam perikatan yang lahir dari perjanjian akibat yang timbul dikehendaki oleh para pihak sedangkan dalam perikatan yang lahir dari UndangUndang, akibat hukum yang timbul ditentukan oleh Undang-Undang yang mungkin saja tidak dikehendaki oleh para pihak. ${ }^{4}$ Dan putusan pengadilan sebagai sumber hukum perikatan tidak diatur secara khusus di dalam KUH.Perdata, namun putusan pengadilan mempunyai kedudukan dan peranan yang sangat penting di dalam hukum perikatan karena putusan pengadilan dapat melengkapi kelemahan-kelemahan dan hambatan dalam penegakan hukum. ${ }^{5}$ Adanya perbedaan sumber perikatan tersebut berpengaruh pada bentuk gugatan jika salah satu pihak nantinya tidak memenuhi hak dan kewajibannya. ${ }^{6}$ Perikatan yang lahir dari Perjanjian, lahir karena antara para pihaknya sepakat atau setuju mengikatkan diri dalam sebuah perjanjian. ${ }^{7}$ Pada perjanjian ini, jika salah satu pihaknya merasa bahwa pihak lain tidak melaksanakan hak dan kewajibannya sesuai dengan perjanjian yang telah disepakati sebelumnya, maka

\footnotetext{
${ }^{2}$ Salim HS, Pengantar Hukum Perdata Tertulis (BW), Cet-11, Sinar Grafika, Jakarta, 2016, h.151. ${ }^{3}$ Burgerlijk Wetboek, Op. Cit., h. 323.

${ }^{4}$ Subekti, Hukum Perjanjian, Cet-18, Intermasa, Jakarta, 2001, h.1.

${ }^{5}$ Salim, HS, OP. Cit., h. 169-171.

${ }^{6}$ Subekti, Op. Cit., h. 1.

${ }^{7}$ Muhammad Syaifuddin, Hukum Kontrak, Cet. 2, CV. Mandar Maju, Bandung, 2016, h. 111.
}

pihak tersebut dapat menuntut pemenuhan hakhaknya dengan mengajukan gugatan wanprestasi ke pengadilan.

Pembentuk Undang-Undang dalam Pasal 1313KUH.Perdata mencoba memberikan suatu definisi mengenai perjanjian atau didalam UndangUndang tersebut disebut persetujuan dengan mengatakan bahwa suatu persetujuan adalah perbuatan dengan mana satu orang atau lebih mengikatkan dirinya terhadap satu orang lain atau lebih. $^{8}$

Pasal 1319 KUH.Perdata menyebutkan dua kelompok perjanjian, yaitu perjanjian yang oleh Undang-Undang diberikan suatu nama khusus atau yang kita sebut sebagai perjanjian bernama (benoemde atau nominaatcontracten) dan perjanjian yang dalam Undang-Undang tak dikenal dengan suatu nama tertentu atau yang kita sebut sebagai perjanjian tak bernama (onbenoemde atau innominaat contracten $)^{9}$

Dalam hukum perjanjian Pasal 1320 KUH.Perdata mengatur syarat sahnya suatu perjanjian yaitu kecakapanbagi mereka yang membuatnya, harus tercapai kata sepakat mereka yang mengikatkan dirinya, harus ada hal tertentu, dan sebab yang halal. Syarat tersebut merupakan landasan seseorang dalam membuat perjanjian. Apabila salah satu syarat tersebut tidak terpenuhi, maka perjanjian tersebut dapat dinyatakan batal demi hukum atau dapat dimintakan pembatalan. ${ }^{10}$

Syarat pertama dan kedua adalah mengenai subjeknya atau pihak-pihak dalam perjanjian sehingga disebut sebagai syarat subjektif, sedangkan syarat ketiga dan keempat disebut syarat objektif karena mengenai objeknya suatu perjanjian.

${ }^{8}$ J. Satrio, Hukum Perikatan, Perikatan yang lahir Dari Perjanjian, Buku 1, PT. Citra Aditya Bakti, Bandung, 2001,h.24.

${ }^{9}$ Ibid, h. 148

${ }^{10}$ Kartini Muljd dan Gunawan, Perikatan Yang lahir Dari Perjanjian, PT. Radja Grafindo Persada, Jakarta, 2003, h. 83. 
Apabila persyaratan subjektif perjanjian (kata sepakat dan kecakapan untuk melakukan perikatan) tidak terpenuhi maka tidak mengakibatkan batalnya perjanjian, tetapi hanya dapat dibatalkan melalui putusan pengadilan. Apabila persyaratan yang menyangkut objek perjanjian (suatu hal tertentu dan adanya causa hukum yang halal) tidak dipenui, maka perjanjian tersebut batal demi hukum.

Kata sepakat di dalam perjanjian pada dasarnya adalah pertemuan atau persesuaian kehendak antara para pihak di dalam perjanjian. Seseorang dikatakan memberikan persetujuannya atau kesepakatannya jika ia memang menghendaki apa yang disepakati. ${ }^{11}$

Pengertian sepakat sebagai persyaratan kehendak yang disetujui antar pihak-pihak. Pernyataan pihak yang menawarkan dinamakan tawaran. Pernyataan pihak yang menerima penawaran dinamakan akseptasi. ${ }^{12}$

Suatu perjanjian dapat mengandung cacat kehendak atau kata sepakat dianggap tidak ada jika adanya paksaan, adanya kesesatan atau kekeliruan, dan adanya penipuan, dan dalam perkembangan lebih lanjut, dikenal pula cacat kehendak yang lain, yakni penyalahgunaan keadaan. ${ }^{13}$

Berdasarkan uraian yang dipaparkan diatas, penulis tertarik untuk melakukan kajian lebih lanjut tentang pembatalan perjanjian sepihak dengan judul "Pembatalan Perjanjian Sepihak Menurut Pasal 1320 ayat (1) KUH.Perdata Tentang Kata Sepakat Sebagai Syarat Sahnya Perjanjian".

\subsection{Rumusan Masalah:}

a. Bagaimana hubungan antara pembatalan perjanjian sepihak dengan perbuatan melawan hukum menurut Pasal 1320 ayat (1) KUH.Perdata ?

\footnotetext{
${ }^{11}$ J. Satrio, Op.Cit, h. 164.

${ }^{12}$ Mariam, Darus Badrulzaman, Aneka Hukum Bisnis, Alumni, Bandung, 1994, h. 24.

${ }^{13}$ Ibid, h. 268.
}

b. Bagaimana akibat hukum dalam pembatalan perjanjian sepihak menurut Pasal 1320 ayat (1) KUH.Perdata?

\section{B. TINJAUAN PUSTAKA}

\subsection{Pengertian Perjanjian Secara Umum}

Dalam KUH.Perdata Pasal 1313, dijelaskan bahwa perjanjian adalah suatu perbuatan dengan nama satu orang atau lebih mengikatkan dirinya terhadap satu orang atau lebih. Sedangkan menurut Prof. Subekti, "Suatu perjanjian adalah suatu peristiwa dimana seseorang berjanji kepada orang lain atau dimana dua orang itu saling berjanji untuk melakukan sesuatu hal. ${ }^{14}$

\subsection{Asas Konsensualitas Dalam Perjanjian}

Asas konsensualitas adalah "ruh" dari suatu perjanjian, yang tersimpul dari kesepakatan para pihak. Namun demikian, pada situasi tertentu terdapat perjanjian yang tidak mencerminkan wujud kesepakatan yang sesungguhnya disebabkan adanya cacat kehendak (wilgebreke) karena kesesatan (dwaling), penipuan (bedrog) atau paksaan (dwang) yang mempengaruhi timbulnya perjanjian. ${ }^{15}$ asas konsensualitas yang terkandung dalam Pasal 1320 ayat (1) KUH.Perdata yang menentukan bahwa perjanjian itu telah lahir cukup dengan adanya kata sepakat, tidak seharusnya ditafsirkan secara gramatikal semata-mata, melainkan harus ditafsirkan juga dalam hubungannya dengan syarat-syarat lainnya dalam Pasal 1320 KUH.Perdata, jika syarat-syarat dalam Pasal 1320 KUH.Perdata tersebut tidak terpenuhi akibat hukumnya adalah perjanjian itu tidak sah dan tidak mempunyai kekuatan mengikat sebagai Undang-Undang.

\subsection{Kebatalan Dan Pembatalan SuatuPerjanjian \\ Kebatalan atau pembatalan perjanjian pada dasarnya adalah suatu keadaan yang menimbulkan akibat suatu hubungan hukum}

${ }^{4}$ Subekti, Pokok-Pokok Hukum Perdata, Cet.24, PT. Internusa, Jakarta, 1992, h.3.

${ }^{15}$ Muhammad Syaifuddin, Op., Cit., h. 78. 
perikatan yang bersumber dari perjanjian itu dianggap tidak pernah ada dengan pembatalan perjanjian maka eksistensi perjanjian dengan sendirinya menjadi berakhir atau hapus. Akibat hukum kebatalan yang mengakhiri atau menghapus eksistensi perjanjian selalu dianggap berlaku surut sejak dibuatnya perjanjian oleh para pihak. ${ }^{16}$

\subsection{Akibat-Akibat Kebatalan Dari Suatu Perbuatan Hukum}

Suatu perbuatan hukum adalah batal, jika perbuatan hukum tersebut tidak menimbulkan akibat-akibat hukum yang dimaksud. Ada kalanya akibat dari suatu perbuatan hukum yang tidak sepenuhnya batal, karena adanya keadaan yang tidak dapat ditiadakan lagi. Misalnya, dari perkawinan yang dibatalkan telah lahir anak-anak atau prestasi yang telah dilaksanakan dari suatu persetujuan obligator yang telah dibatalkan tidak lagi dapat dikembalikan. Kebatalan suatu perjanjian atas dasar ketidakcakapan atau cacad kehendak mempunyai daya berlaku surut (Pasal 1451 dan Pasal 1452). Pada asasnya kebatalan berakibat, bahwa hubungan hukum antara para pihak dipulihkan dalam keadaan sebelum dibuatnya perjanjian. ${ }^{17}$

\section{METODE PENELITIAN}

\subsection{Tipe Penelitian}

Berdasarkan permasalahan yang diteliti penulis, maka metode yang digunakan adalah penelitian hukum yuridis normatif yaituTipe penelitian ini adalah yuridis normatif, metode penelitian hukum normatif atau metode penelitian hukum kepustakaan adalah metode atau cara yang dipergunakan didalam penelitian hukum yang dilakukan dengan cara meneliti bahan pustaka atau data sekunder belaka. ${ }^{18}$

Dalam penelitian ini penulis akan mengkaji pembatalan perjanjian sepihak dalam perspektif

${ }^{16}$ Ibid, h. 434.

${ }^{17}$ Ibid.

${ }^{18}$ Soerjono Soekamto dan Sri Mamudji, Penelitian Hukum Normatif Suatu Tinjauan Singkat, PT Raja Grafindo Persada, Jakarta, 1983, h. 13. peraturan perundang-undangan Pasal 1320 ayat (1) KUH.Perdata tentang kata sepakat sebagai syarat sahnya perjanjian.

Didalam penelitian hukum ini penulis melakukan beberapa pendekatan, yaitu :

a. Pendekatan Konseptual (Conceptual
Approach)

Dilakukan manakala peneliti tidak beranjak dari aturan hukum yang ada. Hal ini dilakukan karena memang belum atau tidak ada aturan hukum untuk masalah yang dihadapi. ${ }^{19}$ Dalam studi putusan ini penulis membangun sebuah konsep untuk dijadikan acuhan didalam penelitiannya dengan mencari pandangan dan doktrin para sarjana di dalam ilmu hukum.

b. PendekatanPerundang-Undangan (Statute Approach),

Dilakukan dengan menelaah semua UndangUndang dan regulasi yang bersangkut-paut dengan isu hukum yang sedang ditanani. ${ }^{20}$

c. Pendekatan Historis (Historis Approach)

Pendekatan historis dilakukan untuk menelaah latar belakang apa yang dipelajari dan perkembangan pengaturan tentang kata sepakat dalam perjanjian sebagai syarat sahnya perjanjian. Di dalam hukum pada umumnya dan bagi para pihak dalam perbuatan hukum khususnya perjanjian.Tujuannya adalah untuk memahami filosofi tentang kata sepakat sebagai syarat sahnya perjanjian bagi pihak-pihak yang akan melakukan perbuatan hukum perjanjian sekaligus dapat memahami perubahan dan perkembangan filosofi yang melandasi peraturan perundang-undangan tersebut.

\footnotetext{
${ }^{19}$ Peter Mahmud Marzuki, Penelitian Hukum, Cet. 12, Ed. revisi, Prenada Media Group, Jakarta, 2016, h. 177.

${ }^{20}$ Ibid, h. 133.
} 


\subsection{Sumber bahan Hukum}

Adapun jenis dan sumber bahan hukum yang akan dipergunakan dalam penulisan penelitian ini terbagi atas tiga yaitu :

a. Bahan Hukum Primer

Yaitu bahan hukum yang bersifat autoritatif, artinya mempunyai otoritas, bahan-bahan hukum primer terdiri dari Perundang-Undangan, catatancatatan resmi atau risalah dalam pembuatan Perundang-Undangan dan putusan-putusan Hakim. ${ }^{21}$ adalah :

1. Kitab Undang-Undang Hukum Perdata (Burgerlijk Wetboek);

2. Kitab Undang-Undang Hukum Dagang;

b. Bahan hukum sekunder

Bahan-bahan hukum sekunder berupa semua publikasi tentang hukum yang bukan merupakan dokumen-dokumen resmi. Publikasi tentang hukum meliputi buku-buku teks, kamus-kamus hukum, jurnal-jurnal hukum dan komentar atas putusan pengadilan. ${ }^{22}$ Kegunaan bahan hukum sekunder adalah memberikan kepada peneliti semacam petunjuk kearah mana peneliti melangkah. Apabila tulisan itu berupa tesis, desertasi ataupun artikelartikel dalam jurnal hukum dan boleh jadi tulisan tersebut memberikan inspirasi bagi peneliti untuk menjadi titik anjak dalam memulai penelitian.

\subsection{Prosedur Pengumpulan Bahan Hukum}

Teknik pengumpulan bahan hukum dilakukan dengan melakukan penelusuran bahan hukum terhadap isu yang akan diangkat. Bahan hukum yang sudah terkumpul, selanjutnya dianalisis dan didepenelitiankan. Bahan-bahan hukum tersebut baik primer, sekunder maupun tersier kemudian digabungkan serta diinterpretasikan, sehingga dapat menemukan penjabaran dan analisis yang paling tepat dari permasalahan yang telah dirumuskan.

\footnotetext{
${ }^{21} \mathrm{Ibid}$, h. 180.

${ }^{22}$ Ibid.
}

Penulisan bahan hukum didasarkan pada keterkaitan serta keterpaduan informasi untuk memperoleh hasil penelitian yang lebih akurat.

\section{HASIL PENELITIAN DAN PEMBAHASAN}

\subsection{PEMBATALAN PERJANJIAN PARA PIHAK DENGAN PERBUATAN MELAWAN HUKUM MENURUT PASAL 1320 AYAT (1) KUH.PERDATA}

. Dalam KUH.Perdata Pasal 1320 sampai Pasal 1337 dijelaskan syarat-syarat sah perjanjian yaitu:

a. Kata sepakat mereka yang mengikatkan dirinya.

b. Kecakapan untuk membuat suatu perikatan;

c. Suatu hal tertentu;

d. Suatu sebab yang halal.

syarat sahnya perjanjian harus memenuhi syarat-syarat yang disebutkan dalam UndangUndang. Syarat tersebut terdiri dari syarat subjektif dan syarat obyektif. Tidak terpenuhinya syarat subjektif yaitu kata sepakat dan kecakapan para pihak pembuatnya, membuat perjanjian tersebut dapat dimintakan pembatalan oleh salah satu pihak. Sedangkan tidak terpenuhinya syarat obyektif yakni hal tertentu dan causa yang halal menyebabkan perjanjian batal demi hukum.

Dapat dibatalkan artinya baru mempunyai akibat setelah ada putusan Hakim yang membatalkan perbuatan tersebut. Sebelum ada putusan, perbuatan hukum yang bersangkutan Undang-Undang menentukan bahwa perbuatan hukum adalah batal demi hukum jika terjadi pelanggaran terhadap syarat yang menyangkut bentuk perbuatan hukum, ketertiban umum atau kesusilaan.

Kebatalan, baik mengenai perbuatan hukum yang batal demi hukum maupun yang dapat dibatalkan dapat dibedakan kedalam relatif dan absolut. Suatu perbuatan hukum adalah batal atau dapat dibatalkan : 
a. Relatif

1. Jika orang-orang tertentu saja yang dapat mengajukan kebatalan;

2. Jika kebatalan hanya berlaku bagi orangorang tertentu.

b. Absolut

1. Jika setiap orang dapat mengemukakan kebatalan;

2. Jika kebatalan berlaku bagi setiap orang.

Perbuatan melawan hukum atau Onrechtmatige daad terdapat dalam Pasal 1365 B.W. memegang peranan penting dalam bidang hukum perdata. Pasal 1365 B.W. memuat ketentuan bahwa setiap perbuatan melawan hukum yang oleh karenanya menimbulkan kerugian pada orang lain, mewajibkan orang yang karena kesalahannya menyebabkan kerugian itu mengganti kerugian.

Pengertian perbuatan melawan hukum dalam rumusan H.R. sebelum tahun 1919 adalah bahwa Onrechtmatige daad, die inbreuk maakt opeens anders subyectief recht, of die in strijd is met des daders eigen rechtplicht(Melawan hukum adalah sekedar suatu perbuatan yang melanggar hak subyektif orang lain atau yang bertentangan dengan kewajiban hukum dari si pembuat sendiri). ${ }^{23}$

Sedangkan pada pemeriksaan di tingkat Kasasi H.R. merumuskan pengertian melawan hukum sebagai berikut ${ }^{24}$ :

a. Melanggar hak subjektif orang lain (hak yang ditentukan Undang-Undang)

Menurut Mayers ciri dari hak subjektif adalah suatu wewenang khusus yang diberikan oleh hukum kepada seseorang untuk digunakan bagi kepentingannya; ${ }^{25}$

${ }^{23}$ R. Setiawan,Pokok Pokok Hukum Perikatan, Cet-5, Binacipta, Bandung, 1994, h.76

${ }^{24}$ Suharnoko, Hukum Perjanjian, Teori dan Analisa Kasus, Cet-3, Kencana, Jakarta, 2004, h. 123.

${ }^{25}$ R. Setiawan, Op., Cit., h. 82. b. Bertentangan dengan kewajiban hukum si pelaku (kewajiban yang ditentukan UndangUndang);

c. Bertentangan dengan tata susila atau bertentangan dengan kepatutan, ketelitian, dan kehati-hatian yang seharusnya dimiliki seseorang dalam pergaulan dengan sesama warga masyarakat atau terhadap harta benda orang lain. ${ }^{26}$

Jika dilihat dari Pasal 1365 KUH.Perdata pengertian perbuatan melawan hukum didefinisikan seperti tersebut diatas, maka salah satu pertimbangan pembatalan perjanjian sepihak dapat digugat dengan gugatan perbuatan melawan hukum, karena dianggap pembatalan sepihak tidak didasari dengan alasan yang dibenarkan menurut kesepakatan mereka untuk dapat dibatalkan, serta dapat dikatakan telah melanggar kewajiban hukum yang juga ada diluar setiap perjanjian, yaitu untuk selalu beritikad baik dan bertindak sesuai dengan kepatutan dan asas kehati-hatian.

Suatu pelanggaran perjanjian atau pemutusan perjanjian yang dilakukan oleh salah satu pihak, dapat juga berupa suatu pelanggaran terhadap Undang-Undang atau suatu perbuatan yang melanggar kepatutan dan kehati-hatian yang harus diperhatikan dalam hubungan antara warga masyarakat dan terhadap benda orang lain. selain itu untuk dapat melihat konsep perbuatan melawan hukum dalam pembatalan perjanjian sepihak. Konsep perbuatan melawan hukum dapat diterapkan pada perkara pembatalan perjanjian sepihak dan salah satu pertimbangan hukumnya adalah bahwa suatu pembatalan sepihak dapat dikatakan merupakan suatu pelanggaran terhadap kepatutan dan bertentangan dengan sikap baik dalam masyarakat. ${ }^{27}$

\footnotetext{
${ }^{26}$ Ibid

${ }^{27}$ Suharnoko, Op. Cit., h. 131.
} 


\section{AKIBAT HUKUM DALAM \\ PEMBATALAN PERJANJIAN \\ SEPIHAK MENURUT PASAL 1320 AYAT (1) KUH.PERDATA}

Perjanjian yang sah tidak dapat ditarik kembali secara sepihak.Perjanjian tersebut mengikat pihak-pihaknya, dan tidak dapat ditarik kembali atau dibatalkan secara sepihak saja.Jika ingin menarik kembali atau membatalkan itu harus memperoleh persetujuan pihak lainnya, jadi diperjanjikan lagi.Namun demikian, apabila ada alasan-alasan yang cukup menurut UndangUndang, perjanjian dapat ditarik kembali atau dibatalkan secara sepihak. ${ }^{28}$

Seperti yang tercantum dalam Pasal 1338 ayat (2) KUH.Perdata. menyebutkan bahwa: "persetujuan-persetujuan itu tidak dapat ditarik kembali selain dengan sepakat kedua belah pihak, atau karena alasan-alasan yang oleh UndangUndang dinyatakan cukup untuk itu".

Dari Pasal 1338ayat (2) KUH.Perdata tersebut, jelas bahwa perjanjian itu tidak dapat dibatalkan sepihak, karena jika perjanjian tersebut dibatalkan secara sepihak, berarti perjanjian tersebut tak mengikat diantara orang-orang yang membuatnya. Jika dilihat dari Pasal 1266 dan 1267 KUH.Perdata,maka jelas diatur mengenai syarat batal jika salah satu pihak tidak memenuhi kewajibannya.Pembatalan tersebut harus dimintakan ke pengadilan, hal ini dimaksudkan agar nantinya tidak ada para pihak yang dapat membatalkan perjanjian sepihak dengan alasan salah satu pihak lainnya tersebut tidak melaksanakan kewajibannya (wanprestasi).

Salah satu pertimbangan pembatalan perjanjian sepihak dapat digugat dengan gugatan perbuatan melawan hukum, karena dianggap pembatalan sepihak tidak didasari dengan alasan yang dibenarkan menurut kesepakatan mereka untuk dapat dibatalkan, serta dapat dikatakan telah melanggar kewajiban hukum yang juga ada di luar setiap perjanjian, yakni untuk selalu beritikad baik dan bertindak sesuai dengan kepatutan dan asas kehati-hatian. Pemutusan perjanjian, memang diatur dalam KUH.Perdata, yakni Pasal 1266, haruslah memenuhi syarat-syarat bahwa perjanjian tersebut bersifat timbal balik, harus ada wanprestasi dan pembatalannya harus memintakan pada hakim (pengadilan).

Suatu sengketa yang telah beralaskan perjanjian yang dibatalkan sepihak dapat digugat dengan konsep perbuatan melawan hukum. Hal ini memperlihatkan adanya kemungkinan hubungan atau kemiripan konsep antara wanprestasi dengan perbuatan melawan hukum, karena kedua-duanya pada dasarnya merupakan perbuatan yang melanggar asas kepatutan dalam masyarakat, sehingga menimbulkan kerugian bagi pihak lain. Dalam hal pembuktian unsur-unsur perbuatanmelawan hukumnya pada pembatalan perjanjian sepihak, hendaknya kembali merujuk pada perspektif teoritis pengertian konsep melawan hukum, yakni dengan menggunakan pengertian konsep melawan hukum dalam arti luas, seperti yang telah diputuskan olehHoge Raaddalam kasus Linden baum versus Cohen,yakni bahwa perbuatan melawan hukum bukan hanya melanggar suatu peraturan tertulis, namun juga dapat disebabkan oleh pelanggaran terhadap hak subjektif orang lain, bertentangan dengan kewajibanhukum si pelaku, melanggar kaidah dan tata susila, serta bertentangan dengan asas kepatutan, ketelitian serta sikap hati-hati yang seharusnya dimiliki seseorang dalam pergaulan dengan sesamawarga masyarakat atau terhadap harta orang lain dalam arti bertentangan dengan sikap yang baik dalam

${ }^{28}$ Subekti, Pokok-Pokok Hukum Perdata, Cet. 24, PT. Intermasa, Jakarta, 1992. 
bermasyarakat untuk memperhatikan kepentingan orang lain. ${ }^{29}$

Tindakan wanprestasi membawa konsekuensi terhadap timbulnya hak pihak yang dirugikan untuk menuntut pihak yang melakukan wanprestasi untuk memberikan ganti rugi, sehingga oleh hukum diharapkan agar tidak ada satu pihak yang dirugikan karena wanprestasi. Wanprestasi mengakibatkan salah satu pihak dirugikan, oleh karena pihak lain dirugikan akibat wanprestasi tersebut, maka pihak yang melakukan wanprestasi harus menanggung akibat dari tuntutan pihak lawan yang dapat berupa tuntutan :

a. Pembatalan kontrak (disertai atau tidak disertai ganti rugi);

b. Pemenuhan kontrak (disertai atau tidak disertai ganti rugi).

Dengan demikian, kemungkinan pokok yang dapat dituntut oleh pihak yang dirugikan adalah pembatalan dan pemenuhan kontrak.

Dalam KUH.Perdata, pengaturan tentang kerugian dan ganti rugi dirumuskan dalam 2 (dua) pendekatan sebagai berikut: ${ }^{30}$

a. Ganti Rugi Umum

Yakni ganti rugi yang berlaku untuk semua kasus, baik untuk kasus-kasus wanprestasi kontrak, maupun kasus-kasus yang berkenaan dengan perikatan lainnya termasuk di dalamnya perbuatan melawan hukum.

Ketentuan tentang ganti rugi umum ini dalam KUH.Perdata diatur dalam bagian keempat dalam buku ketiga, mulai dari Pasal 1243 sampai Pasal1252. dalam hal ini untuk ganti rugi tersebut, KUH.Perdata secara konsisten untuk ganti rugi digunakan istilah:

\section{Biaya}

Yang dimaksud dengan biaya adalah setiap cost atau uang, atau apapun yang dapat dinilai dengan uang yang telah dikeluarkan secara nyata oleh pihak yang dirugikan, sebagai akibat dari wanprestasi dari kontrakatau sebagai akibat dari tidak dilaksanakannya perikatan lainnya, termasuk perikatan karena adanya perbuatan melawan hukum.

\section{Rugi}

Dalam arti sempit, yang dimaksud dengan rugi atau kerugian adalah keadaan berkurang atau merosotnya nilai kekayaan kreditursebagai akibat dari adanya wanprestasi dari kontrak atau sebagai akibat dari tidak dilaksanakannya perikatan lainnya, termasuk perikatan karena adanya perbuatan melawan hukum.

\section{Bunga}

Merupakan suatu keuntungan yang seharusnya diperoleh, tetapi tidak jadi diperoleh oleh pihak kreditur karena adanya wanprestasi dari kontrak atau sebagai akibat dari tidak dilaksanakannya perikatan lainnya, termasuk perikatan karena adanya perbuatan melawan hukum. Pengertian bunga ini lebih luas dari pengertian bunga sehari-hari yang hanya berarti "bunga uang" (interest), yang hanya dihitung dari persentase hutang pokoknya.

b. Ganti Rugi Khusus

Yakni ganti rugi khusus terhadap kerugian yang timbul karena perikatan-perikatan tertentu. Dalam hubungan dengan ganti rugi yang terbit dari suatu perbuatan melawan hukum. Selain dari ganti rugi dari bentuk yang umum.

Bentuk dari ganti rugi terhadap perbuatan melawan hukum yang dikenal oleh hukum adalah sebagai berikut: ${ }^{31}$

${ }^{29}$ Ibid., h. 19.

${ }^{30}$ Wirjono Prodjodikoro,Perbuatan Melawan Hukum, Cet-9, Sumur Bandung, Bandung, 1993, h. 136. 
a. Ganti Rugi Nominal

Jika adanya perbuatan melawan hukum yang serius, seperti perbuatan yang mengandung unsur kesengajaan, tetapi tidak menimbulkan kerugian yang nyata bagi korban, maka kepada korban dapat diberikan sejumlah uang tertentu sesuai dengan rasa keadilan tanpa menghitung berapa sebenarnya jumlah kerugian tersebut.

b. Ganti Rugi Kompensasi

Merupakan ganti rugi yang merupakan pembayaran kepada korban atas dan sebesar kerugian yang benar-benar telah dialami oleh pihak korban dari suatu perbuatan melawan hukum.

c. Ganti Rugi Penghukuman

Ganti rugi penghukuman (punitivedamages) merupakan suatu ganti rugi dalam jumlah besar yang melebihi dari jumlah kerugian yang sebenarnya. Biasanya jumlah ganti rugi tersebut sebagai hukuman bagi si pelaku. Ganti rugi penghukuman ini layak diterapkan pada kasuskasus kesengajaan yang berat atau sadis.

d. Ganti Rugi Aktual

Merupakan ganti rugi terhadap kerugian yang benar-benar telah dialami secara nyata. Ganti rugi yang aktual merupakan ganti rugi yang paling umum dan gampang diterima oleh hukum, baik dalam hal perbuatan melawan hukum maupun dalam hal wanprestasi kontrak. ${ }^{32}$

e. Ganti Rugi Yang Berhubungan Dengan Tekanan Mental

Merupakan ganti rugi yang biasanya berupa pemberian sejumlah uang yang diberikan kepada korban dari perbuatan melawan hukum disebabkan korban telah menderita tekanan mental, ganti rugi jenis ini juga disebut dengan ganti rugi 'immateril'.

f. Ganti Rugi Untuk Kerugian Yang Akan Datang

Ganti rugi ini haruslah terhadap kerugian yang akan datang, yang dapat dibayangkan yang

${ }^{32}$ Ibid, h. 144. wajar dan secara nyata akan terjadi, jadi bukan kerugian yang cuma dikhayalkan atau dikarangkarang. Bila ganti rugi karena perbuatan melawan hukum berlakunya lebih keras sedangkan ganti rugi karena kontrak lebih lembut itu adalah salah satu ciri dari hukum dijaman modern.

Berdasarkan pedoman beberapa Pasal dalam KUH.Perdata sendiri dan pertimbangan Hakim dalam jurisprudensi, maka aturan yang dipakai untuk ganti kerugian ini adalah, dengan secara analogis mempergunakan peraturan ganti kerugian akibat wanprestasi yang diatur dalam Pasal 12431252 KUH.Perdata, disamping itu pemulihan kembali ke dalam keadaan semula. ${ }^{33}$

Gugatan pengganti kerugian dalam perbuatan melawan hukum dapat berupa: ${ }^{34}$

a. Uang dan dapat dengan uang pemaksa;

b. Pemulihan pada keadaan semula;

c. Larangan untuk mengulangi perbuatan itu lagi (dengan uang pemaksa);

d. Dapat minta putusan Hakim bahwa perbuatannya adalah perbuatan melawan hukum.

Jika dalam ganti kerugian karena wanprestasi, biasanya besarnya kerugian telah terlebih dahulu ditentukan besar dan ketentuannya dalam perjanjian, sedangkan dalam hal ganti kerugian karena perbuatan melawan hukum, Hakim mempunyai kebebasan untuk menerapkan besarnya ganti rugi tersebut sesuai dengan asas kepatutan, sejauh hal tersebut memang dimintakan oleh pihak penggugat, bahkan telah menjadi jurisprudensi tetap dari Mahkamah Agung Indonesia bahwa Hakim dalam menentukan besarnya ganti kerugian harus menetapkan menurut keadilan, walaupun hal ini sangat tergantung pada penilaian subjektif Hakim yang menangani. Adakalanya untuk

${ }^{33}$ Rosa Agustina,Perbuatan Melawan Hukum, Program Pascasarjana Fakultas Hukum Universitas Indonesia, Jakarta, 2003, h. 85.

${ }^{34}$ Ibid. 
kepentingan penetapan besarnya ganti kerugian terlebih dahulu harus meminta seorang ahli untuk melakukan transaksi tentang besarnya kerugian.

Biaya-biaya yang harus dikeluarkan untuk keperluan tersebut disebut biaya-biaya expertise, yang harus juga diganti oleh pelaku. Lebih sukar adalah untuk menetapkan besarnya gederfdewinst (keuntungan yang diharapkan dapat diterima) maka karenanya dalam memperhitungkan gederfdewinstorang selalu memperhitungkan secara ex aequo ex bono(naar redelijkheid en billijkheidatau menurut kelayakan dan kewajaran). Demikian pula kerugian idiil selalu akan diperhitungkan ex aequo ex bono. ${ }^{35}$ Namun kemungkinan menerapkanex aequo ex bonotersebut tidak berarti memberi kewenangan pada hakim untukmengurangi pembayaran ganti rugi berdasarkan keadaan pribadi para pihak, juga harus diusahakan memberi ganti rugi yang betul-betul diderita.

Kerugian ditentukan secara objektif menurut kekayaan dari orang terhadap siapatelah dilakukan wanprestasi. KUH.Perdata sendiri mengenai besarnya ganti rugi akibat Perbuatan Melawan Hukum mengaturnya dalam Pasal 1371 (2) yang menyatakan bahwa ganti rugi dinilai menurut kedudukan dan kemampuan kedua belah pihak, dan menurut keadaan. ${ }^{36}$

Sekalipun dalam prinsipnya semua kerugian yang timbul harus diberi ganti, namun jelaslah kiranya bahwa Pasal 1365 KUH.Perdata tidak mencakup kerugian yang diderita karena suatu kepentingan yang tidak sah. Umpamanya, kerusakan yang diderita pada mobil selundupan, maka pemilik mobil tersebut akan berhak penggantian atas kerugian materiilnya, akan tetapi tidak berhak menuntut keuntungan yang diharapkan akan diterima. ${ }^{37}$

${ }^{35} \mathrm{Ibid}, \mathrm{h} .78$

${ }^{36} \mathrm{Ibid}$, h. $224-225$

${ }^{37} \mathrm{Ibid}$, h. 79
Besarnya kerugian ditetapkan dengan penafsiran, dimana diusahakan agar si penderita sebanyakmungkin dikembalikan pada keadaan semula sebelum terjadinya perbuatan melawan hukum. Mengenai bunyi Undang-Undang yang mengatakan bahwa Hakim dalam menentukan besarnya ganti kerugiantidak boleh melebihi dari apa yangdituntut oleh penggugat. ${ }^{38}$

Akan menimbulkan permasalahan jika menurut Hakim apa yang dituntut oleh penggugat dianggap lebih kecil dan belum memenuhi rasa keadilan. Jika demikian adanya, hendaknya Hakim memutus ganti rugi masih dalam apa yang dituntut oleh penggugat. Hal ini untuk menghindari upaya hukum lain yang bisa saja menganggap putusan Hakim yang melebihi tuntutan penggugat adalah tidak benar, dan akhirnya putusan yang semulaingin memberikan rasa adil pada suatu perkara, malah dibatalkandan penggugat yang mengharapkan gantirugi untuk menuntut keadilan, tidak mendapatkan keinginan mereka karena alasan legisme semata.

\section{E. PENUTUP}

\subsection{KESIMPULAN}

a. Suatu pelanggaran perjanjian atau pemutusan perjanjian yang dilakukan oleh salah satu pihak, dapat juga berupa suatu pelanggaran terhadap Undang-Undang atau suatu perbuatan yang melanggar kepatutan dan kehati-hatian yang harus diperhatikan dalam hubungan antara warga masyarakat dan terhadap benda orang lain. selain itu untuk dapat melihat konsep perbuatan melawan hukum dalam pembatalan perjanjian sepihak. Konsep perbuatan melawan hukum dapat diterapkan pada perkara pembatalan perjanjian sepihak dan salah satu pertimbangan hukumnya adalah

${ }^{38}$ Ibid, h. 91 . 
bahwa suatu pembatalan sepihak dapat dikatakan merupakan suatu pelanggaran terhadap kepatutan dan bertentangan dengan sikap baik dalam masyarakat.

b. Pemutusan perjanjian memang diatur dalam KUH.Perdata yakni Pasal 1226 haruslah memenuhi syarat-syarat bahwa perjanjian tersebut bersifat timbal balik, harus ada wanprestasi, dan Pembatalannya harus memintakan pada Hakim (pengadilan). Namun jika pembatalan yang dilakukan tidak memenuhi syarat tersebut, maka dapat dikatakan perbuatan pembatalan tersebut melanggar Undang-Undang Pasal 1226 KUH.Perdata.

\subsection{SARAN}

a. Diperlukan kesepakatan para pihak dalam membuat suatu perjanjian sehingga tidak terjadi suatu pembatalan secara sepihak, karena dalam hal ini ada dari pihak yang melakukan perjanjian merasa dirugikan sehingga dibuat suatu pembatalan secara sepihak dari para pihak yang membuat perjanjian. Dalam membuat perjanjianharus ditentukan keabsahannya disamping itu harus juga dipenuhi syarat-syarat yang ditentukan oleh undang-undang, dalam hal ini Pasal 1320 KUH.Perdata.

b. Diharapkan dalam kehidupan sehari-hari dalam melakukan perjanjiansebaiknya dibuat atau disepakati oleh itikad baik dan orang yang cakap, serta dalam setiap perjanjian diperlengkapi dengan aturan Undang-Undang dan adat kebiasaan di suatu tempat, di samping kepatutan karena kebiasaan juga ditunjuk sebagai sumber hukum disamping Undang-Undang, sehingga kebiasaan itu turut menentukan hak dan kewajiban pihak-pihak dalam perjanjian.

\section{DAFTAR PUSTAKA}

Agustina, Rosa, Perbuatan Melawan Hukum, Program Pascasarjana Fakultas Hukum Universitas Indonesia, Jakarta, 2003.

Darus Badrulzaman, Mariam, Aneka Hukum Bisnis, Alumni, Bandung, 1994. Kompilasi Hukum Perikatan, Citra Aditya Bakti, Bandung, 2001.

H.S.,Salim,Hukum Kontrak, Teori dan Teknik Penyusunan Kontrak, Sinar Grafika, Jakarta, 2003.

Pengantar Hukum Perdata Tertulis (BW), Cet-11, Sinar Grafika, Jakarta, 2016.

L.C., Hoffmann, Het Nederlandsch Verbintenissen Recht, Jilid 1, De Algemene Leer Der Verbintenissen, Cet-4, J.B. Wolters Groningen Batavia,1935.

Mahmud Marzuki, Peter, Penelitian Hukum, Cet. 12, Ed. revisi, Prenada Media Group, Jakarta, 2016.

Muljd, Kartini dan Gunawan, Perikatan Yang lahir Dari Perjanjian, PT. Radja Grafindo Persada, Jakarta, 2003.

Miru, Ahmadi, Hukum Kontrak Perancangan Kontrak, PT. RajaGrafindo Persada, Jakarta, 2008..

Mertokusumo,Sudikno, Hukum Acara Perdata, Liberty, Yogyakarta, 1999.

Prodjodikoro, Wirdjono, Perbuatan Melawan Hukum, Cet-9, Sumur Bandung, Bandung, 1993.

Setiawan, R., Pokok Pokok Hukum Perikatan, Cet5, Binacipta, Bandung, 1994

Subekti, R., Pokok-Pokok Hukum Perdata, Cet. 24, PT. Intermasa, Jakarta, 1992.

., Hukum Perjanjian, Intermasa, Jakarta, 1984.

, Hukum Perjanjian, Cet-18, Intermasa, Jakarta, 2001.

Soekamto, Soerjono, dan Sri Mamudji, Penelitian Hukum Normatif Suatu Tinjauan Singkat, PT Raja Grafindo Persada, Jakarta, 1983.

Syaifuddin, Muhammad, Hukum Kontrak, Cet. 2, CV. Mandar Maju, Bandung, 2016.

Satrio, J., Hukum Perikatan, Perikatan yang lahir Dari Perjanjian, Buku 1, PT. Citra Aditya Bakti, Bandung, 2001. 


\section{Perundang - undangan}

Undang-Undang Dasar Republik Indonesia;

Kitab Undang-Undang Hukum Perdata (Burgerlijk Wetboek);

Kitab Undang-Undang Hukum Perdata;

Kitab Undang-Undang Hukum Dagang

Kitab Bahasa Indonesia

\section{Karya Ilmiah}

Anindya, Prita, Pembatalan Perjanjian Sebagai Perbuatan Melawan Hukum, Penelitian, Fakultas Hukum Universitas Indonesia, Penelitian, Depok, 2008.

Irmantius, David, Tinjauan Yuridis Pembatalan Perjanjian Secara Sepihak Sebagai Suatu Perbuatan Melawan Hukum, Penelitian, Depok, 2013.

\section{Jurnal}

Panggabean, R. M., Keabsahan Perjanjian dengan klausul Baku, Jurnal Hukum, Vol. 17, No. 4, 2010, h. 651-667.

Asmawardhani, Dewi, Analisis Asas Konsensualisme Terkait Dengan Kekuatan Pembuktian Perjanjian Jual-Beli Di Bawah Tangan, Ganec Swara, Vol. 9, No. 1, 2015, h. 167-176.

Weydekamp, Gerry R., Pembatalan Perjanjian Sepihak Sebagai Suatu Perbuatan Melawan Hukum, Lex Privatum, Vol. I, No. 4, 2013, h.148-158.

\section{Data Daring}

Tunardy, Wibowo, Syarat-syarat Sahnya Perjanjian,

2012,<http://www.jurnalhukum.com/syara t-syarat-sahnya-perjanjian/>diakses pada tanggal 09November 2017. 